WARSZTATY Z GEOGRAFII TURYZMU

ISBN 978-83-7525-925-4 $\quad$ s. 105-113

http://dx.doi.org/10.18778/7525-925-4.09

Sylwia KOWNACKA

Uniwersytet Łódzki

\title{
TURYSTYKA KULTUROWA W BELGRADZIE
}

\section{Wstęp}

Podróże o charakterze poznawczym do miast są zjawiskiem znanym od starożytności. Ludzi od zawsze fascynowały obiekty o wartościach historycznych, artystycznych, religijnych, instytucje kulturalne, a także odmienne style życia mieszkańców odwiedzanych miejscowości. Wyjazdy tego typu zaliczane są do tzw. turystyki kulturowej.

Turystyka kulturowa jako jedna z kluczowych form turystyki definiowana jest w różny sposób, m.in. jako „aktywność osób w ich miejscach pobytu turystycznego oraz podczas podróży z miejsca stałego zamieszkania, która pozwala na poznanie lub doświadczenie różnych sposobów życia innych ludzi, sposobów odzwierciedlających obyczaje społeczne, tradycje religijne, myśl intelektualną dziedzictwo kulturowe i mających na celu zaspokojenie ludzkich potrzeb, pragnień oraz oczekiwań w zakresie kultury" (MARCISZEWSKA 2002). W myśl innej definicji (KUREK 2007), turystyka kulturowa „obejmuje wszelkie podróże, których głównym celem jest odwiedzanie i poznawanie miejsc oraz obiektów o wartości historycznej, artystycznej i kulturowej, a także uczestnictwo w imprezach o charakterze kulturalnym". 
Turystykę kulturową, według A. MIKOSA VON ROHRSCHEIDTA (2008) można podzielić na kilka kategorii:

1. Turystyka kultury wysokiej (turystyka dziedzictwa kulturowego, turystyka muzealna, turystyka literacka, turystyka eventowa - turystyka imprez i wydarzeń kulturalnych);

2. Turystyka edukacyjna.

3. Turystyka kultury popularnej (np. turystyka żywej historii, turystyka obiektów militarnych, przemysłowych, technicznych, turystyka kulinarna $\mathrm{i}$ inne).

Analizując publikacje poświęcone turystyce kulturowej można dostrzec, że do najważniejszych jej elementów należą dziedzictwo materialne i duchowe oraz szeroko rozumiane imprezy i wydarzenia kulturalne, które niewątpliwie najczęściej utożsamiać należy z przestrzenią miejską. Właśnie miasto od zawsze stanowiło centrum społeczne, polityczne, administracyjne, a także kulturalne.

Celem niniejszej pracy jest zaprezentowanie na przykładzie Belgradu, jednej z postsocjalistycznych stolic europejskich, wybranych form współczesnej miejskiej turystyki kulturowej oraz przedstawienie wyników wywiadów eksperckich z pracownikami Belgradzkiej Organizacji Turystycznej.

Miejska turystyka kulturowa oparta na zróżnicowanym, wielowiekowym dziedzictwie kulturowym odgrywa niezwykle istotną rolę w kształtowaniu przestrzeni turystycznej miast historycznych. Do takich ośrodków zaliczany jest Belgrad, jedno z najstarszych miast europejskich, którego początki sięgają IV/III w. p.n.e., a najstarsze ślady osadnictwa pochodzą sprzed 9000 lat (BATAKOVIĆ 2000). Bogate, wielokulturowe dziedzictwo wspomnianego miasta są kluczowe dla rozwoju szeroko pojętej turystyki kulturowej.

\section{Wybrane formy turystyki kulturowej w Belgradzie}

Jak wspomniano wcześniej, dziedzictwo kulturowe jest najistotniejszym elementem przestrzeni turystycznej Belgradu. Turystyka dziedzictwa kulturowego to najważniejsza i najbardziej promowana forma turystyki w serbskiej stolicy. Opiera się ona na wielowiekowej historii i wielokulturowości miasta. Zatem prezentowana praca poświęcona będzie głównie omówieniu wspomnianych wcześniej form turystyki kultury wysokiej. Autorka ma jedno- 
cześnie świadomość, że nie są to jedyne uprawiane w Belgradzie formy turystyki kulturowej.

Największe nagromadzenie elementów dziedzictwa kulturowego występuje w centrum Belgradu, stanowiącym najważniejszą a zarazem najstarszą część miasta, malowniczo położoną u ujścia rzeki Sawy do Dunaju (rys. 1). Właśnie na tym obszarze koncentruje się ruch turystyczny, na co wpływa również usytuowanie najważniejszych wydarzeń kulturalnych i obecność prestiżowych instytucji kulturalnych.

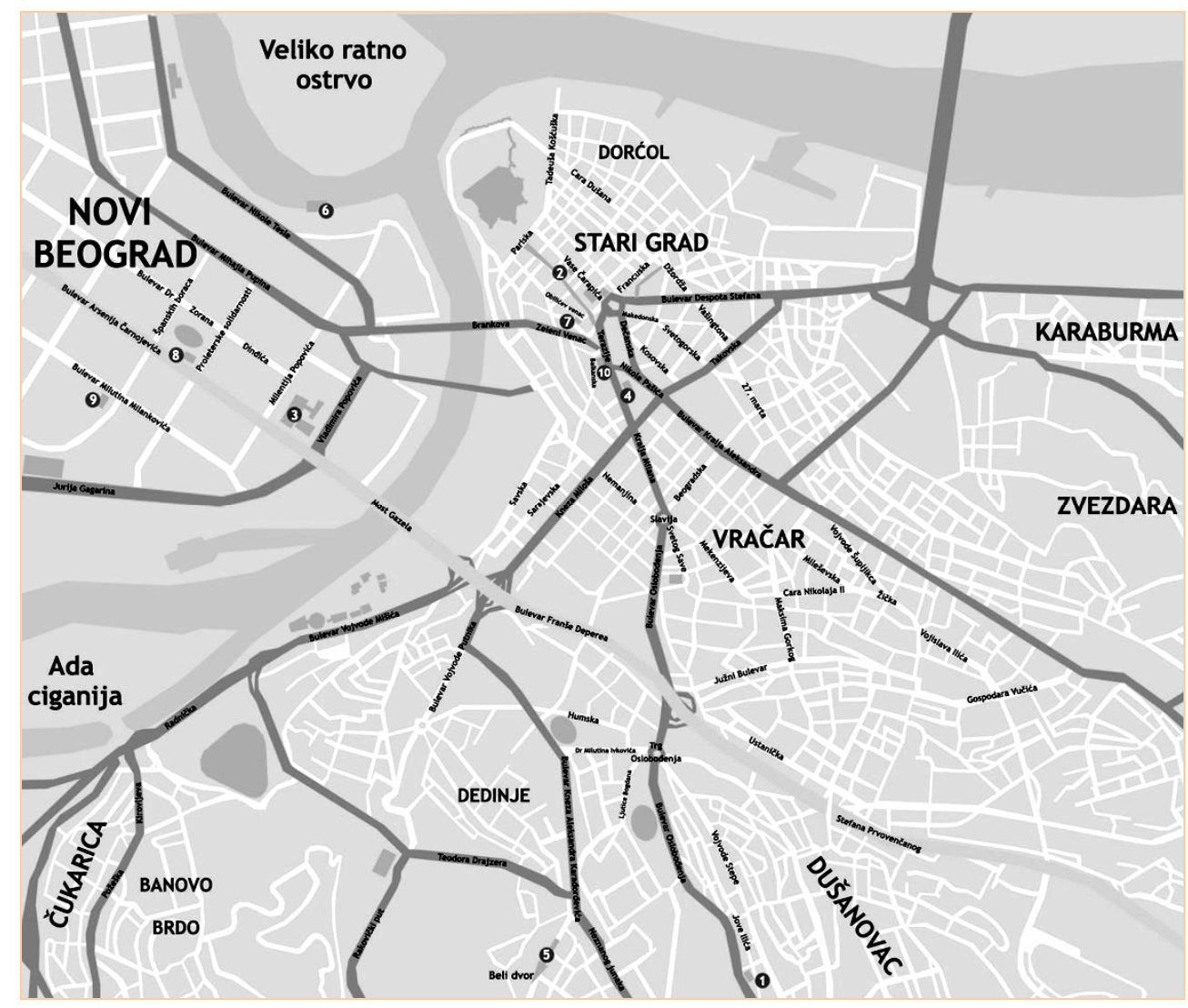

Rys. 1. Centrum Belgradu (skala $1: 18$ 000)

Źródło: http://apartmanibeogradnadan.com/mapa-grada

Do sztandarowych walorów materialnego dziedzictwa kulturowego Belgradu należą: 
1) Twierdza Belgradzka w parku Kalemegdan (fot. 1) - dawny rzymski obóz Singidunum, z zachowanymi fragmentami średniowiecznych fortyfikacji, studniami rzymskimi oraz pozostałościami potureckimi (Cox 2002);

2) kompleks królewski - Stary Dwór, Biały Dwór - pamiątki z czasów Zjednoczonego Królestwa Serbów, Chorwatów i Słoweńców;

3) Zemun - dawny rzymski obóz Taurunum, od XVIII w. pod panowaniem Habsburgów;

4) cerkiew św. Sawy - największa serbska świątynia prawosławna wybudowana w stylu serbsko-bizantyjskim, na wzór słynnej Hagia Sofia w Istambule;

5) cerkiew św. Marka - zbudowana w stylu kosowsko-metohijskim;

6) XVI-wieczny monastyr Rakovica;

7) XVI-wieczny meczet Bajrakli - jedyny zachowany z ponad 80 dawniej funkcjonujących meczetów;

8) ulice: Skadarska (historyczne miejsce spotkań belgradzkiej bohemy artystycznej), Księcia Michała (pochodzący z XIX w. deptak, najdroższa ulica), Terazije (pełna zabytków z XIX i XX w.).

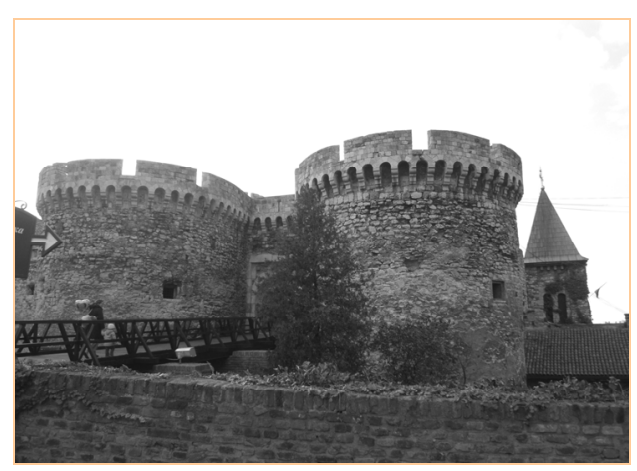

Fot. 1. Twierdza Belgradzka w parku Kalemegedan Fot. S. Kownacka

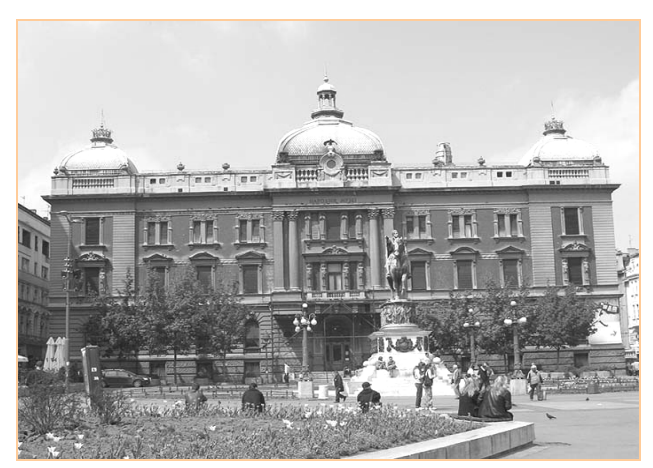

Fot. 2. Muzeum Narodowe w Belgradzie Fot. S. Kownacka

Do turystyki kultury wysokiej zalicza się również turystyka muzealna. W Belgradzie znajduje się ponad 30 placówek muzealnych o zróżnicowanej tematyce. Do najciekawszych i najczęściej odwiedzanych należą: 
- Muzeum Narodowe (obecnie nieczynne z powodu remontu) (fot. 2),

- Muzeum Etnograficzne,

- Muzeum Twierdzy Belgradzkiej,

- Muzeum Ivo Andricia,

- Mauzoleum Josipa Bros Tito („Dom kwiatów”),

- Muzeum Miasta Belgradu,

- Muzeum Historii Jugosławii,

- rezydencja księcia Miłosza,

- rezydencja księżnej Ljubicy,

- Muzeum Historii Żydowskiej,

- Muzeum Wojska,

- Muzeum Serbskiego Kościoła Prawosławnego,

- Muzeum Historii Naturalnej,

- Muzeum Lotnictwa,

- Muzeum Nikoli Tesli,

- Muzeum Sztuki Afrykańskiej,

- Muzeum Sztuki Współczesnej,

- Muzeum Pedagogiczne.

Oprócz muzeów w Belgradzie znajdują się inne instytucje kulturalne: ponad 10 teatrów (Teatr Narodowy od 1868 r.), opera, galerie sztuki oraz kina. Większość wspomnianych placówek kulturalnych zlokalizowana jest w historycznym centrum miasta lub w jego bezpośredniej okolicy.

Turystyka kultury wysokiej obejmuje ponadto tzw. turystykę imprez i wydarzeń kulturalnych (eventowa). Corocznie w serbskiej stolicy odbywa się ponad 40 prestiżowych wydarzeń kulturalnych. Część z nich ma charakter cykliczny i kilkudziesięcioletnią tradycję. Należą do nich: Belgrade International Theatre Festival (BITEF) (od 1967 r.), Belgrade Music Festival (od 1969 r.), Belgrade Film Festival (od 1971 r.), BEMUS, Jazz Festiwal, Belgradzki Karnawał Łodzi, Festiwal Piwa (JOvANOVIĆ 2007).

Interesującą inicjatywę kulturalną w ostatnich latach podjęła Belgradzka Organizacja Turystyczna. Impreza nosi intrygującą nazwę „Belgradyzacja Belgradu" i ma na celu promowanie kultury, dziedzictwa kulturowego, aktywizowanie mieszkańców i turystów, a przede wszystkim kreowanie nowego wizerunku Belgradu jako miasta nowoczesnego, pełnego imprez i bogatego w interesujące obiekty kulturalne.

Warto ponadto wspomnieć o jednej z najstarszych, największych i najważniejszych imprez literackich w Europie - Międzynarodowych Targach 
Książki. Są to nie tylko targi, na których można nabyć po okazyjnej cenie publikacje książkowe, ale również liczne imprezy kulturalne, wykłady naukowe, koncerty, festyny, itd. Od lat frekwencja na targach jest bardzo duża. W 2010 r. łączna liczba odwiedzających przekroczyła 143 tys. (dane Belgradzkiej Organizacji Turystycznej).

W Belgradzie odbywają się również inne wydarzenia kulturalne. W roku 2008 miasto było gospodarzem Konkursu Piosenki Eurowizji, w 2009 r. XXV-letniej uniwersjady oraz kilku ważnych wydarzeń sportowych.

Obecnie serbska stolica ubiega się o miano Europejskiej Stolicy Kultury 2020 r. Belgradzka Organizacja Turystyczna zamierza w związku z tym podjąć kilka nowych inicjatyw w celu podniesienia atrakcyjności i konkurencyjności miasta, a także poszerzenia jego oferty kulturalnej.

\section{Turystyka kulturowa w Belgradzie w świetle wywiadów przeprowadzonych z pracownikami Belgradzkiej Organizacji Turystycznej}

W październiku 2011 r. autorka opracowania przeprowadziła wywiady eksperckie z trzema pracownikami Turystycznej Organizacji Belgradu (TOB). Celem badania było uzyskanie informacji na temat działań prowadzonych przez TOB, rozwijanych form turystyki, nowych trendów turystycznych w Belgradzie, planów na przyszłość oraz sposobu kreowania nowego wizerunku miasta.

Pracownicy podkreślają że najważniejszą i najbardziej intensywnie rozwijaną formą belgradzkiej turystyki jest turystyka kulturowa oparta na bogatym, wielowiekowym i wielokulturowym dziedzictwie miasta, instytucjach kulturalnych oraz licznych wydarzeniach i imprezach nawiązujących do przeszłości, a także nowoczesnych. Od kilku lat TOB prowadzi kampanie promujące tę formę turystyki. Wydawane są liczne publikacje, informatory, foldery, filmy itd. ukazujące dziedzictwo kulturowe miasta i zachęcające do odwiedzin turystów zarówno krajowych, jak i zagranicznych.

Jako podstawową barierę rozwoju turystyki w Belgradzie, pracownicy TOB wymieniają brak odpowiednich nakładów na rozwój turystyki oraz powszechnie panujące stereotypy na temat Serbii i Belgradu - spowodowane przede wszystkim krwawym rozpadem Jugosławii i wydarzeniami w Koso- 
wie. Serbia jest postrzegana jako państwo niebezpieczne, biedne i niezbyt interesujące.

Belgrad jest najczęściej jednym z punktów podczas wycieczek objazdowych po Bałkanach, lub dla grup jadących docelowo np. do Grecji czy Turcji. TOB uznaje to $\mathrm{z}$ jednej strony za formę promocji, $\mathrm{z}$ drugiej widzi $\mathrm{w}$ tym poważny problem, gdyż odwiedzający jednodniowi nie generują tak dużych dochodów jak turyści zostający dłużej.

Na podstawie pomiarów ruchu turystycznego Belgradzka Organizacja Turystyczna opracowała profil belgradzkiego turysty, charakteryzującego się poniższymi cechami:

a) wiek: 35-50 lat,

b) wyższe wykształcenie,

c) mieszkaniec miasta,

d) długość pobytu: do 3 dni,

e) turysta indywidualny,

f) środek transportu: samolot, samochód,

g) samodzielnie organizuje wycieczki po mieście (bez przewodnika).

Badania TOB wykazały, że Belgradem zainteresowani są ludzie młodzi i w wieku średnim, wykształceni, przyjeżdżający na krótko i indywidualnie, własnym środkiem transportu, lub samolotem. Najczęściej są to osoby uprawiające, nawiązując do wspomnianego podziału A. Mikosa von Rohrscheidta, tzw. turystykę kulturową wysoką (głównie turystykę dziedzictwa kulturowego, muzealną i eventową - udział w festiwalach, koncertach i innych imprezach kulturalnych) oraz turystykę biznesową.

Również z transportem lotniczym wiążą się pewne problemy. Na żadne serbskie lotnisko, w tym belgradzkie im. Nikoli Tesli w dzielnicy Surczin, nie docierają tzw. tanie linie lotnicze, przez co loty do Serbii są bardzo drogie, niedostępne dla wielu turystów.

Zamierzenia TOB w najbliższym czasie to dalsza, bardziej intensywna kampania promująca dziedzictwo kulturowe miasta, podejmowanie nowych inicjatyw kulturalnych (imprezy i wydarzenia, budowanie centrum kulturalnego w dzielnicy Nowy Belgrad) oraz pozyskiwanie większych nakładów finansowych na rozwój turystyki.

Zdaniem pracowników TOB, ogromną szansą dla Belgradu byłoby otrzymanie miana Europejskiej Stolicy Kultury 2020. Umożliwiłoby to poprawę wizerunku i atrakcyjności miasta, rozwój kultury i turystyki kulturowej oraz wzrost wielkości ruchu turystycznego. 
Obecnie miasto jest odwiedzane głównie przez mieszkańców państw ościennych: (Słowenia - 44 tys. odwiedzających, Czarnogóra - 37 tys., Chorwacja - 29 tys.) i Niemców (25 tys.). Polska plasuje się na dalekim, 17. miejscu (6 tys. turystów) (Statistical Yearbook of Belgrade 2011). Turyści z pozostałej części Europy oraz z innych kontynentów odwiedzają miasto niezwykle rzadko. Na turystycznej mapie Europy Serbia i Belgrad nie zajmują istotnej pozycji, stąd to prestiżowe miano byłoby szansą na zaprezentowanie atutów serbskiej stolicy.

\section{Podsumowanie}

Turystyka kulturowa jest najważniejszą formą turystyki belgradzkiej, a zarazem szansą na przełamanie stereotypów i wykreowanie nowego, pozytywnego wizerunku. Najistotniejszym elementem przestrzeni turystycznej Belgradu jest materialne dziedzictwo kulturowe związane $\mathrm{z}$ bogatą historią i wielokulturowością. Największe nagromadzenie elementów dziedzictwa kulturowego oraz zagospodarowania turystycznego, a zarazem największe natężenie ruchu turystycznego występuje w centrum miasta stanowiącym jednocześnie jego historyczny rdzeń.

W ostatnich latach zanotowano niewielki wzrost turystyki przyjazdowej do Belgradu, przy jednoczesnym spadku odwiedzin turystów krajowych. Belgradzka Organizacja Turystyczna, podejmując działania na rzecz poprawy wizerunku turystycznego stolicy i jego atrakcyjności, zamierza podjać szeroko pojęte działania na rzecz rozwoju turystyki kulturowej, jak również biznesowej. Jedną z podjętych w ostatnim czasie inicjatyw jest próba zainteresowania turystów zagranicznych weekendowymi odwiedzinami Belgradu, tzw. city break.

Poza licznymi walorami kulturowymi Belgrad imponuje dobrze rozwiniętą bazą towarzyszącą (m.in. kluby, dyskoteki, puby), co potwierdza ranking australijskiego dziennika The Sydney Morning Herald z 2007 r., w którym Belgrad uplasował się na pierwszym miejscu wśród miast świata o najbardziej rozwiniętym życiu nocnym, wyprzedzając m.in. Montreal, Buenos Aires i Dubaj. 
Rozwój belgradzkiej turystyki, w tym turystyki kulturowej, może się stać dla serbskiej stolicy szansą na poprawę wizerunku, jak i sytuacji ekonomicznej oraz społecznej miasta.

\section{BIBLIOGRAFIA}

BATAKOvić D., 2000, Nova istorija srpskog naroda, Naš dom/ L' Age d' Homme, Belgrad-Lozanna. Cox J., 2002, The history of Serbia, Greenwood Press, London.

JovANOvić G., 2007, Belgrade, Branmil, Beograd.

KUREK W., 2007, Turystyka, PWN, Warszawa.

MARCISZEWSKA B., 2002, Społeczno-ekonomiczne uwarunkowania rozwoju turystyki kulturowej w Polsce, „Problemy Turystyki i Hotelarstwa” 3.

MIKOS VON ROHRSCHEIDT A., 2008, Turystyka kulturowa: fenomen, potencjat, perspektywy, GWSHM Milenium, Gniezno.

Statistical Yearbook of Belgrade 2011, 2011, Institute for Informatics and Statistics, Belgrade. http://apartmanibeogradnadan.com/mapa-grada/, www.aztux.com. 